\title{
GELIEFDES, BLY EN ARBEI IN DIE LIEFDE VAN GOD
}

Die rede by die Promosieplegtigheid van die Teologiese Skool Potchefstroom op 19 November 1981 deur prof. F. N. Lion-Cachet plaas ons graag as redaksionele artikel omdat hy hierin die lig van die skrif oor ons akademiese roeping laat val.

Ons lewe in 'n tyd waarin daar veelvuldige leerstellige probleme voorkom en skokkende gebeurtenisse plaasvind. Ek wil daarom die klem nie laat val op die kennis (die kognitiewe aspek) van die teologie nie maar liewer op die liefde (die affektiewe aspek) tot God en sy openbaring wat soveel vir ons leer en lewe beteken. Ons bevind ons inderdaad in 'n kookpotsituasie waarin die erns van die verkondiging van die evangelie aan afgedwaaldes baie aandag geniet; leerstellige probleme en dwalinge rondom die werk van die Heilige Gees, die doop, die gesag van die Skrif baie gemoedere geraak het; op kerklike gebied is daar steeds die dreiging om grense te vervaag en valse belydenisse uit te spreek. Op sedelike gebied word ons telkens deur skokkende gebeurtenisse tot stilstand geruk. Ter oplossing van hierdie probleme in leer en lewe kan ons met 'n koue verstandelike ontleding tot konklusies kom, maar ons sal alleen deur die emosie van die Christelike liefde staande kan bly om verder te arbei.

Die aktualiteit van Gods woord in Judas 20-23 het my getref. In die Nuwe Afrikaanse Vertaling lui die teks as volg: "Julle geliefdes, moet egter voortgaan om julle lewe te bou op julle allerheiligste geloof. Bid altyd deur die krag van die Heilige Gees. Bly in die liefde van God. Vestig steeds julle verwagting op die barmhartigheid van ons Here Jesus Christus wat die ewige lewe aan julle sal gee. Oor die wat in twyfel verkeer, moet julle julle ontferm. Ander moet julle red deur hulle uit die vuur te ruk. Oor ander moet julle jul in versigtigheid ontferm; en verafsku selfs die klere wat deur sondige luste besmet is".

Ek wil kortliks wys op: Geliefdes van God, bly in Sy liefde en arbei in Sy liefde.

\section{Geliefdes van God.}

' $n$ Regte uitgangspunt en 'n regte voorveronderstelling is onontbeerlik vir enige teologie. Indien die teoloog nie by God begin wat Homself aan die mens geopenbaar het nie, eindig hy waar hy begin het naamlik by die mens. Wie die gesag van God se Woord betwyfel, eindig met die Bybel as 'n literêre produk van mense. Die beskouing daarin sal dan hoogstens as menslike beskouinge oor teologiese, sosiologiese- of antropologiese aangeleenthede gewaardeer kan word. Dan verdwyn die lewende God van die teologie. Judas het die regte beginpunt beklemtoon. Voordat hy tot geloofsvolharding en liefdesbetoon oproep, adresseer hy weer eens sy boodskap deur te sê: "Geliefdes". Daarmee sluit hy aan by die inleidende woorde in sy brief (v. 1) waar hy sy brief rig tot die mense wat God die Vader lief het en wat deur Jesus Christus bewaar en geroep is. Die werk van God kom eerste. Dit is God wat liefhet, wat roep, wat in stand hou. Dit 
is God uit Wie, deur Wie en tot Wie alle dinge is. God is geen veraf en koue wetenskaplike begrip nie. Hy het lief, Hy roep en $\mathrm{Hy}$ bewaar deur sy Gees en Woord.

Die liefde van God is self openbarend. Ons ken gewoonlik liefde as ' $n$ bedwelmende emosie wat sy bevrediging op liggaamlike vlak soek. Die Griek sou van eros of eran gespreek het. Ons ken ook die liefde op 'n hoër vlak naamlik op die geestelike vlak waarin twee mense mekaar ontmoet en wat soms in vriendelikheid, sagmoedigheid in tederheid wat hulle teenoor mekaar bewys, gesien kan word, Die Griekse woord fileo kom hiermee ooreen. Daar is baie wat sê dat hierdie liefde juis in die kerk ervaar moet word en dat dit juis altyd in die kerk gesien moet word. As dit nie ervaar word nie, word die kerk beskuldig van koudheid. Die Nuwe Testament gebruik ook hierdie twee liefdesbegrippe maar as van Gods liefde gespreek word en die mens tot liefde opgeroep word word 'n ander woord gebruik wat die volkome liefde omskrywe (agape). Die geliefdes in die kerk is daarom nie die wat mekaar vriendelik en hartlik groet nie, hulle is nie diegene wat mekaar teder aankyk nie, maar hulle is die mense wat God liefhet d.w.s. hulle is mense wat God self aktief uitkies en in sy liefde koester. Die woord liefde omvat die volgende: God kies sy geliefdes, sluit met hulle 'n verbond, gee aan hulle ryke beloftes en Hy verwag van hulle absolute lojaliteit.

Niks kan dan ook skeiding maak tussen hierdie liefde van God en sy geliefdes nie. Hy wil steeds die afstand wat daar tussen Hom en die mens is, oorkom. In die Hoëpriesterlike gebed bid Jesus dan ook "dat almal een mag wees net soos U, Vader, in My en Ek in U, dat hulle ook in Ons een mag wees" (Joh. 17:21). God se liefde is alles behalwe ' $n$ koue veraf emosielose begrip. As die sonde en die Satan dreig om skeiding te maak tussen God en sy geliefde kinders, leer ons die grootheid, en die diepte van sy liefde in die soendood van sy Seun Jesus Christus ken: "So lief het God die wêreld gehad dat hy sy eniggebore Seun gegee het, sodat elkeen wat in Hom glo nie verlore mag gaan nie, maar die ewige lewe kan hê" (Joh. $3: 16$ ). So word Gods liefde van alle ewigheid deur Jesus Christus deurgetrek tot alle ewigheid. Liefde word 'n eindbegrip, dit sal nooit vergaan nie.

Judas was van plan om 'n mooi brief te skrywe oor die verlossing waaraan die geliefdes van God deel het. Hy het egter daarvan afgesien omdat daar dwalinge gekom het wat gedreig het om hierdie liefde van God te verduister. Daar was mense wat hulle aanvanklik as gelowiges betoon het en deur die gemeente opgeneem is, maar hulle het hulleself onbeskaamd en met 'n selfversekerde hoogmoed teen die liefdesopenbaring van God begin stel (v. 8-13). Hulle het verleiers geword wat op ' $n$ vleiende manier probeer het om ander te beinvloed en ander nader te trek (v. 16f). By die liefdesmaaltyd was hulle teenwoordig terwyl hulle terselfdertyd skaamteloos met uitspattige sondige dade voortgegaan het (v. 12). Dit was asof hulle sou sê: "God het ons mos ewig lief, Hy het ons mos verlos, daarom kan ons maar in sonde voortlewe want niks kan ons mos van die liefde van God skei nie".

Judas het hierdie dwaalleraars met ontstemde gemoed geteken. Hy vergelyk hulle met Kain wat sy broer doodgeslaan het; met Korag 
wat teen die wettige gesag in opstand gekom het en met Bileam wat Israel na die uitspattige heidense feeste uitgenooi het. Ja, hulle was soos die inwoners van Sodom en Gomorra wat geen respek vir ware liefde en sedelikheid gehad het nie. Hulle wil die geliefdes van God wat hulle in die sonstrale van God se liefde gekoester het, in die skaduwee van hulle eie dwaalleer en sedeloosheid bring.

Nou kan ons met reg vra: Is dit moontlik dat iets ons van Gods liefde kan skei. Dit is mos onmoontlik! Ja, maar dit hef ons verantwoordelikheid nie op nie. God se liefde wek wederliefde en wie nie wederliefde het nie, het God se liefde nog nooit geken nie. Dit is daarom so noodsaaklik dat Judas die mense roep om in die liefde van God te bly. Niks mag 'n skaduwee op die pragtige straling van God's liefde op sy geliefdes bring nie.

2. Die roeping om in die liefde van God te bly.

God het die mens nie 'n stomme dier gemaak nie. Die geliefdes van God moet in hulle leer en lewe antwoord gee met 'n soortgelyke liefde as wat God aan hulle bewys het. Daarom volg op die aanspraak "geliefdes" in vers 20 en 21 vier reëls. Uit die Grieks is dit duidelik dat die hoofklemtoon op die bevel val: "Bly in die liefde van God". Die twee sinne wat vooraf gaan en die een wat daarop volg verduidelik hoedat hulle God wel liefgehad het, maar is ook die riglyn en aansporing om daarop voort te beweeg, d.w.s. om meer liefde te bewys, om nader na God te beweeg. Wie God liefhet moet voortgaan in die liefde totdat die volmaakte gekom het.

Om in die liefde van God te bly vereis eerstens om voort te gaan om op die allerheiligste geloof te bou. Hier word gepraat van geloof, dit is die verkondiging van die heil en die verlossing in Jesus Christus (vergelyk v. 3). Dit is ook die ganse verkondiging van die apostels. Meer omvattend gestel: Dit is die volle leer van die saligheid, die waarheid van die ganse Woord van God. Dit is allerheiligs omdat daar niks mee vergelyk kan word nie. Dit is nie die slim uitgedinkte filosofieë van mense nie, dit is nie kunstig geskrewe literatuur nie, maar hierdie "geloof", d.w.s. hierdie geloofswaarheid is deur God self gegee as sy openbaring, sodat ons dit kan ondersoek om so in sy liefde te bly. Niemand mag dus tevrede wees met die kennis van God wat hy reeds besit nie. Niemand kan stil staan by die kennis wat hy in katkisasie opgedoen het nie. Geen predikant kan 'n streep trek na die kennis wat hy op teologiese skool ingesamel het nie. Elkeen moet voortgaan om dag na dag sy kennis aan te vul en so nader aan die Here te beweeg. Preke kan en moet weer herhaal word want so kom ons tot die rypste vrug van naprediking. Maar as 'n predikant net tevrede is om ou preke te preek of om die standaard van sy preke jaar na jaar op dieselfde pyl te hou sonder om verder te studeer, is dit liefdeloos!

Om in die liefde van God te groei vereis tweedens ook ' $n$ verdieping van gesindheid. Dit is nie net die verstand wat op die geloofswaarhede gevestig moet word nie, dit is ook die hart wat op God gerig moet wees. Daar moet ' $n$ toename wees in warme liefdestoegeneentheid. Daar moet ' $n$ beweging kom en daarom vermaning: Bid in die Heilige Gees. Die geliefdes aan wie Judas geskrywe het, het seker gebid en ons bid seker ook baie. Daarin spreek ons met die 
Here deur ons lofsange en ons dank Hom oor sy genadegawes. Ons kla ons nood by Hom. As dit goed gaan is ons dankbaar voor Hom, as dit sleg gaan worstel ons in ons geduld.

Gebede is tog immers die asemhaling van ons siel waarin ons al ons emosies, al ons belewinge voor ons God bring. So bly ons in die liefde van God.

Ons kan egter baie van hierdie dinge doen sonder dat ons hart daarin is. Ons kan psalmversies opsê sonder om Hom te eer. Ons kan lang gebedsrieme omhang sonder die Heilige Gees. Judas beklemtoon daarom die hart van ons gebede: Bid in die Heilige Gees. Die teenwoordigheid van die Heilige Gees was by die uitstorting in tonge van vuur gesien. Hy laat mense in tale praat! Maar dit is nie die enigste of absolute teken van Sy teenwoordigheid nie. Dit is selfs nie die belangrikste nie. Die belangrikste is dat die Heilige Gees in die binneste van die mens kom om hom te oortuig van sonde en ongeregtigheid om tot die belydenis van Jesus Christus te bring. "Hy sal in julle binneste kom en maak dat julle in sy insettinge wandel en sy verordeninge onderhou en doen" (Eseg. 30:27). Die Heilige Gees dring en dryf die mens om met blydskap die Evangelie aan ander te gaan verkondig. Wie in die Heilige Gees bid, kan daarom nie maar rustig op 'n gevestigde lewenspatroon bly sit nie. Hy sal dag na dag homself meer en meer bekeer om die beeld van Jesus Christus te vertoon. Hy sal opstaan om met krag en vuur die evangelie aan ander te gaan verkondig. Daar is beweging waar die Heilige Gees werk.

' $n$ Derde aspek, om in die liefde van God te bly, word genoem: "Vestig steeds julle verwagting op die barmhartigheid of op die ontferming van ons Here Jesus Christus wat die ewige lewe aan julle sal gee". Vestig julle aandag: Dit is: verwag, wag bewaak die skat van die ewige lewe. Waak, wag op, dit is 'n aktiewe daad. So het die wagte Paulus in die tronk bewaak. So moet gewaak word op die ontferming van ons Here Jesus Christus. Die uitsig op die ewige lewe moet altyd helder en skoon bly. Niks mag hierdie beloftes wegraap nie. Verwag, konsentreer daarop, dit is asof ons die hemelse skat kan sien en ons mag nie toelaat dat iets ons blik verduister of ons aandag aftrek nie. Ons mag nie na eer of roem of rykdom begin kyk nie. Ons mag nie in klein menslikhede verstok raak nie, maar moet met 'n lewende hoop op dit wat Christus ons wil gee, wag. Wie hierdie verwagting nie het nie sal moedeloos word. Moedeloosheid is soos 'n gordyn wat alles bedek sodat ons nie meer die liefde van God kan sien nie. Moedelose mense ken nie die liefde van Christus nie. 'n Ware liefde tot God en die Christelike hoop bring aktiwiteit. So bly ons in die liefde van Jesus Christus en in die liefde van God.

Met bogenoemde drie vermaninge word die geliefdes van God geroep om in sy liefde te bly. Daar is sprake van geloof, hoop en liefde. En weer eens is dit die liefde wat sentraal staan.

3. Arbei in die liefde van God.

Met drie kort sinne stuur Judas die geliefdes 'n sondige wereld in. Die drie sinne kan so samgevat word: Ontferm julle oor die twyfelaars, red die wat in dic vuur is en ontferm julle terwyl julle die sondes vrees. Dit is drie sinne met 'n geweldige betekenis. So moet die mens uitgaan om evangelisasie te doen. Met evangelisasie word 
hier die evangelie wat aan almal verkondig moet word, bedoel. Hierin word die metode en die beginsel van evangelisasie gestel. Die klem val ongetwyfeld weer op die middelste sin: "Red hulle wat in die vuur is, deur hulle uit te ruk". Die woord "red" is dieselfde woord wat so dikwels i.v.m. ons Here Jesus Christus gebruik word. Hy het gekom om die mens te red.

Geliefdes julle moet die wat in die vuur van sonde en van Godsoordeel is, gaan uitruk! Julle moet as redders optree! Julle moet hulle gaan vrymaak! Julle moet hulle weer in 'n ruimte bring waarin hulle vry kan beweeg, waar hulle weer vry kan asemhaal! Christus is natuurlik die enigste Redder. In sy redding gebruik Hy egter eenvoudige mense in sy diens. As iemand in die vuur is help dit nie om met versuikerde woorde na hom te kom nie. As iemand na vuur toe slinger, moet jy haastig gaan en hom weggryp. Des te meer geld dit as dit die vuur van God se oordeel is. Die oordeel is 'n eindbegrip. Aan die einde van die dae sal die vuur van God se oordeel kom en dit sal vir die ongelowiges die ewige hel beteken. As een uitgaan om te red moet hy die eindbegrip nader bring. Hy moet aan hulle verkondig dat hulle hulle in die vuur sal bevind as hulle in die sonde verhard. Ruk hulle daaruit! Skok hulle daar weg!

Dit is nie die volledige program nie. Hierdie woorde moet gelees word soos hulle in noue verband staan met die sin wat volg en die een wat voorafgaan gegee is. Dit is twee bevele van Judas: Ontferm julle oor die twyfelaars, ontferm julle terwyl julle die sonde vrees. Tweekeer word die woord "ontferm" herhaal. Judas wil die begrip inhamer. Ons mag ook nie aan hierdie woorde peuter nie. Dit moet ingeslaan word. Ontferm julle! Hierdie woorde spreek van emosie! Ontferming kom ooreen met 'n Ou Testamentiese begrip wat te doen het met verbondsliefde. As julle na die twyfelaars toe gaan moet julle ontferm, moet julle verbondsliefde betoon. Daar is 'n gemeenskap tussen julle en daardie sondige mense wat begin twyfel het. Die twyfelaars waarvan hier sprake is, is heel waarskynlik nog in die gemeente. As julle na die swakkelinge in die gemeente toe gaan, betoon verbondsliefde en arbei in die liefde. God het deur Jeremia gesê: "Ek het jou met 'n ewige liefde liefgehad, daarom het ek jou getrek met my verbondsliefde". Broeders, in hierdie gesindheid moet julle uitgaan om in die gemeentes te gaan werk: Vervul met verbondsliefde. Omdat julle sondes julle vrygeskeld is, moenie 'n mede-skuldige aan die keel gaan gryp en hom dwing om alles te moet betaal nie.

Arbei in die liefde en as julle ontferming bewys wees bang dat die sonde julle mag inhaal. As julle langs die sondaars gaan staan, moenie die minste toegee nie, moenie saam met hulle sonde doen nie, moenie vasgevang word in hulle sonde nie. Judas probeer dit duidelik maak deur te sê: Julle moet selfs die klere waarop daar sondige spatsels is, nie aanraak nie. Klere kan nie sondig nie, maar dit is die kleed waarin die sonde soms getooi word. Vrees die sonde! Lees nie sondige geskrifte nie! Kyk nie na sondige prente nie! Speel nie met sonde nie! 